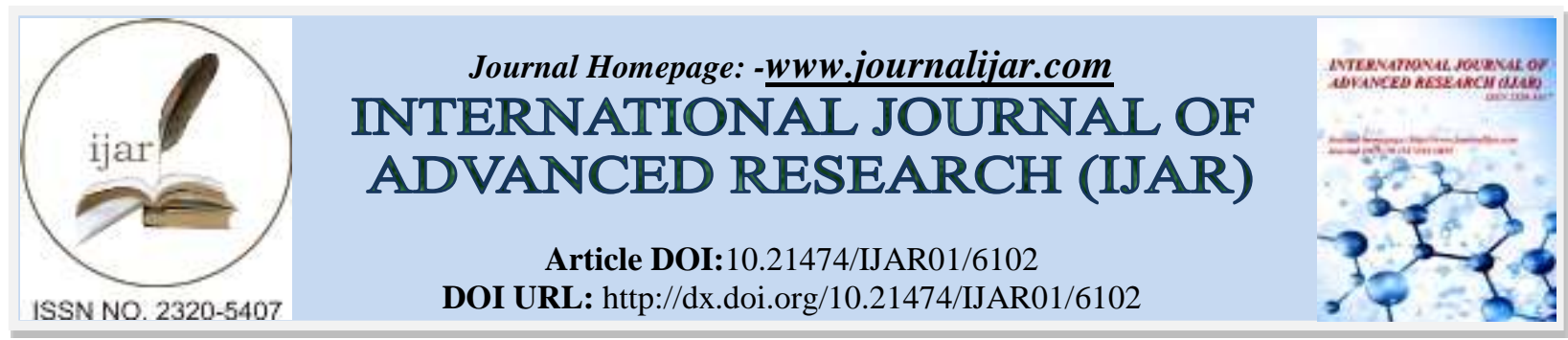

RESEARCH ARTICLE

\title{
A GIS BASED ROUTE OPTIMIZATION FOR SOLID WASTE MANAGEMENT: A CASE STUDY ON INDAPUR MUNICIPALITY.
}

\author{
M. S. Lawand ${ }^{1}$, S. S. Bansode ${ }^{1}$ and Dr. P. D. Nemade ${ }^{2}$.
}

1. Assistant Professor, Department of Civil Engineering, S B Patil COE, Indapur, Savitribai Phule Pune University, Pune, India.

2. Principal, S B Patil COE, Indapur, Savitribai Phule Pune University Pune, India.

\section{Manuscript Info}

Manuscript History

Received: 19 October 2017

Final Accepted: 20 November 2017

Published: December 2017

Key words:-

Solid waste; Indapur City Municipal

Corporation (ICMC); Geographical

Information System (GIS); route

optimization; transportation;

environment; Municipal Solid Waste (MSW).

\begin{abstract}
This paper emphasizes on existing solid waste management practices in Indapur municipal area of Pune district of Maharashtra state, India. Exponential growth of population and in round development of society and industries are responsible for increased solid waste generation in city. Whereas uncontrollable and mismanaged solid waste cause adverse environmental impacts on public health and are basis of other socio-economic problems too. For reducing the expenditure on Solid Waste Management (SWM), route optimization for collection of solid waste is major component. The objective of this paper is to give a better alternative for solid waste disposal management system by route optimization using Geographical Information System for the city. This could help not only to the competent responsible authorities in municipal solid waste management but also the researchers in this field to enhance the efficient planning and strategies in this field.
\end{abstract}

Copy Right, IJAR, 2017,. All rights reserved.

\section{Introduction:-}

Wastes created by various human activities are handled, stored, collected and disposed off in various ways. Thus the waste management imposes the risk to the environment and as a result to public health if waste is improperly managed (Saxena et al., 2010; Zhu et al., 2008). The economic development, urbanization and improved living standards in cities lead to increased amount of solid waste quantity and its complexity (Gidde et al., 2008; Rathi, 2007). Generally amount of waste produced is linearly associated with economic prosperity of the concerned community (Singh et al., 2014). The continuous indiscriminate disposal of MSW is hastening and is allied with poverty, poor governance, urbanization, population growth, deprived standards of living, low level of environmental awareness and inadequate management of environmental knowledge (Rachel et al., 2009; Ogu, 2000). Solid wastes include the waste generation from various zones such as residential, commercial, institutional, industrial, agricultural, etc. Many times household and commercial wastes are considered together as urban wastes (Syed, 2006). Thus municipal solid waste (MSW) is ordinarily consists of domestic and commercial waste produced from the concerned community (Rajkumar et al., 2010). Further MSW mainly includes degradable (e.g. paper, textiles, food waste, etc.), partially degradable (e.g. wood, disposable napkins and sludge, etc.) and non-degradable materials (e.g. leather, plastics, electronic waste, etc.) (Jha et al., 2011; Herat, 2009).

About 4 billion metric tons of solid waste (SW) is generated worldwide annually. According to State Pollution Control Boards in India, 127486 Tons per day MSW is generated in year 2011-12. Considering the statistics 70\% of 
total MSW generated is collected and out of which only $12.45 \%$ is processed. (Central pollution control board, India). Table 1 gives few statistics regarding MSW generation in Indian cities.

Further in the recent years the large quantity of MSW is generated daily due to migration of people in and nearby areas of cities. This is outcome of fastly growing industrialization and population surge in India. Accordingly the complexity in Solid waste management is increasing and the requisite resources availablability for providing service to citizens are shrinking (Sanjeevi V and Shahabudeen P, 2015). Lack in collection system and insufficient transportation are responsible for the accumulation of MSW at roadside areas. (Bundela et al., 2010; Gidde et al., 2008). Thus in urban areas, enormous amounts of MSW generated daily impose stress on existing facilities to treat and dispose off the solid waste. This makes MSW management crucial.

Consequently due to scientific disposal of MSW hostile impact arises on the environment and human health (Rathi, 2007). It give the impression in improper management of solid waste in different areas of developing countries and the same has been reported by several researchers (Das and Bhattacharya, 2013). Improperly handled solid waste causes diverse environment impacts as well as detrimental effects on living being. India is one of the least urbanized countries of the world, yet its urban population is second largest amongst the countries of the world. Metropolitan cities (viz. Delhi, Mumbai, Chennai and Kolkata) have the population more than $42 \%$ of India's total urban population (Ghosh and Kansal, 2014). Out of these metropolitan cities Delhi found to be a topmost MSW producer in India due to its high occupancy. In the present study, an alternate proposal is suggested for optimized transportation of solid waste for disposal which can optimize the whole SWM of Indapur City Municipal Corporation.

\section{Study area and existing waste management systems:- \\ Study area:}

The proposed SWM system is designed for Indapur City Municipal Corporation (ICMC). Indapur city (latitude: $18.12^{0}$; longitude: $75.02^{0}$, Elevation: $527 \mathrm{~m}$ ) is a taluka place covering an area of 14680 hector situated in Pune district of Maharashtra state, India. (source: www.indiamapia.com). Refer Fig. 1. Projected population for year 2021 is about 25000 where a decadal growth rate is of about $5.17 \%$ and average annual growth rate is about $1.05 \%$. For the analysis of population, area under the jurisdiction of ICMC is considered. For details refer Table 2. The Indapur municipality has total 17 wards decentralised in four zones viz. residential, commercial, hospital and industrial zone. Details of wards are enlisted in Table 3.

\section{Quality of waste:-}

Physical characteristic:

At Indapur density of waste is found in range of $168 \mathrm{~kg} / \mathrm{m}^{3}$. Whereas Moisture content of solid waste is observed about 26\% during normal season and 52\% during monsoon. However, during winter the moisture content is noted near to average i.e. 26 to $29 \%$.

\section{Composition of municipal solid waste in Indapur:}

Due to escalating urbanization and change in community lifestyle, the rapid increase in amount of MSW and invariable changes in its composition can be observed. Fig. no. 3 illustrates the composition of MSW for Indapur city. The MSW collected in the Indapur city mainly consists of Domestic waste, waste from commercial areas, wastes from hotels and restaurants, vegetable and fruit market, bio-medical waste, and industrial solid wastes. As waste generation depends upon community lifestyle and food habit, large amount of refuse is collected in high income group followed by middle and low- income group.

Typical flow chart MSW management are represented in Fig.2. ICMC also follows the same for managing the solid waste in the city.

\section{Collection and storage of waste:}

The Indapur Municipal area for solid waste collection is further classified in 6 various divisions. Refer Fig. 4. Waste generation in the area is about 10 tons/day and the average per capita MSW generation is $0.167 \mathrm{~kg} / \mathrm{day}$. The details of six health units are given in the Table 4.

Solid waste containers i.e. Street litter bin are provided all over the city. However, MSW in city is collected through street sweeping with the use of traditional short-handled brooms and Door to Door collection system of domestic 
waste by six number of TATA ACE Hoppers for some part of city. The solid waste in municipal area is collected through 6 subdivisions. The solid waste collection is $100 \%$ in city. Presently sweeping, collection and transportation activities are done by sanitary workers in the municipality. Further a tractor is used for transporting the collected waste to dumping ground. Refer Fig.5. Details of collection systems are enlisted in Table 5.

\section{Transportation of waste:}

Transportation of solid waste includes lifting of closed container, lifting of dead animals and lifting of silt from Nalla. The transportation of unattended waste in open plots and unwept waste in slums is also done manually and/or mechanically through variety of vehicles. Approximately four to five closed container of waste are emptied into a bigger tipper at transfer station which is taken for final transfer to land fill site by one tractor.

\section{Processing of Waste:}

Indapur City Municipal Corporation has appointed Jay Bhavani Biometric Pvt. Ltd. Baramati. For the processing of biomedical waste ICMC disposes the unsegregated Solid Waste on the dumping ground. Further the material is transferred to the segregation section where waste is isolated in various forms such as wet, Dry, recyclable and inert wastes. The waste processing and disposal plant is located at Baramati on Built Operate and Transfer basis by Jay Bhavani Biometric Pvt. Ltd. Wet waste being degradable is transferred to the window platform where the Bioculture helps in composting of waste. Moreover Recyclable material is conveyed to the recycle plant and inert material along with debris will be transported to the landfill. Plastic material is also reprocessed and utilized as byproduct helping in saving the cost of project.

\section{Disposal of Waste:}

The inert material leftover after processing are dumped at ITI ground site which are approximately $25 \%$ of total collected waste.

\section{Proposed GIS based Route optimization of solid waste collection system:-}

In the present work two cases in view of alternate disposal points are considered. In first case only a single dumping site is considered where the entire solid waste of the city of Indapur is dumped. This is an existing set-up at city. In second case one extra site is proposed at different location in the city. The cost economics of both the cases has been worked out bearing in mind expenditure with respect to transportation of MSW, site maintenance, labour required. Thus the two cases are compared.

The total waste generated from 6 health units in Indapur city is about 10 tons per day. For transporting this waste from source to dumping site, Ghantagadi are required.

\section{Case I: single Dumping Site:-}

In this case the solid waste collected at six health components is transported to single dumping site located near ITI College in south area of Indapur. The entire waste is expected to be land filled. Total quantity of waste collected per day and distances between generation node and dumpsite are showed in table 6.

\section{Case II: Two Dumping Sites:}

In second case total three dumping sites are considered viz. near ITI College (Akluj road depot), Kalthan road depotand opposite Tembhurni Naka. Optimized distances are obtained from various combinations of health units and dumping sites with the help of QGIS previously known as Quantum GIS software. The key point in using this software is its flexibly in manoeuvre. It is user friendly, easily available in market. Besides it is open source desktop GIS. Application provides data viewing, editing and analysis. The optimized routes for all the health units are mentioned in Fig. 7, 8, 9, 10, 11 and 12. Refer Table 7 shows for the details of minimum distances.

\section{Estimating Transportation Cost:-}

Transportation cost of MSW includes cost of vehicle, cost of fuel, salaries of driver and helper and operation and maintenance cost of Vehicles. Transportation cost is calculated with the reference to "Municipal Solid Waste Management on a Regional Basis by Ministry of Urban Development Government Of India".

\section{Expenditure on vehicles required:}

Refer Table 8. 


\section{Assumptions:-}

- Quantity of waste generated/collected in Tons per day (TPD):10

- Rejects from compositing facility (@35\%) (TPD):3.5

- Vehicle capacity (Ghantagadi): $1 \mathrm{~T}$

- Maximum number of trips per truck per day: 1.5

- Vehicle speed- counting tipping time, vehicle stoppages and halts: (average) $25(\mathrm{~km} / \mathrm{hr}$.)

- Vehicle mileage ( $\mathrm{km}$ per litre): 4.5

- Cost of vehicle (INR): 8,00,000

- Maintenance of vehicle: $6 \%$ of Capital

- Current diesel price (INR /litre): 65

- Salary of driver (INR per month): 8,000

- Salary of helper (INRPer month): 5,000

Expenditure on fuel consumption:

Refer Table 9 and 10 for estimating expenditure in Case I and II respectively.

Expenditure on salary:

Refer Table 11 for calculation of associated salaries.

Operation \& Maintenance cost:

Refer Table 12 for operation and maintenance cost of vehicles.

Estimation Total cost of transportation of $S W$ :

Refer Table 13 and 14 for total cost of transportation in case of Case I and Case II respectively.

\section{Results and Discussions:-}

In solid waste management system, collection and transportation of solid waste is the most important process for total disposal cost. As solid waste disposal is an essential service, requisite investments in it have to be justified on the basis of least cost and technologically feasible option for achieving maximum efficiency. The total cost of transportation for both considered cases is estimated as in table 3.14 and 3.15. Presently ICMC is spending around 19 lakh annually as in case I for collection of SW in city. In order to decrease the total disposal cost it is necessary to perform route optimization on current solid waste transportation paths (Case I). Thus optimized route for final transportation of MSW is revealed as in Case II which saves lot of cost as well as makes Solid waste transportation and its management more efficient.

\section{Conclusion:-}

In the present work an effort has been made to design and develop an appropriate collection, transportation plan for the Indapur city Municipality Corporation (ICMC). Here GIS based optimal model is developed and used to trace the least cost. This minimum cost is with respect to distance efficient collection path in transferring the solid waste to the open dumping ground. Case II with three different dumping sites and associated minimum paths could be adopted as it saves around 3 lakhs than the current expenditure on SWM. Thus the proposed model can be adopted by the concerned authority. Further use of GIS can be adopted as a decision support tool by the municipal authorities for efficient solid waste management with respect to transportation issues.

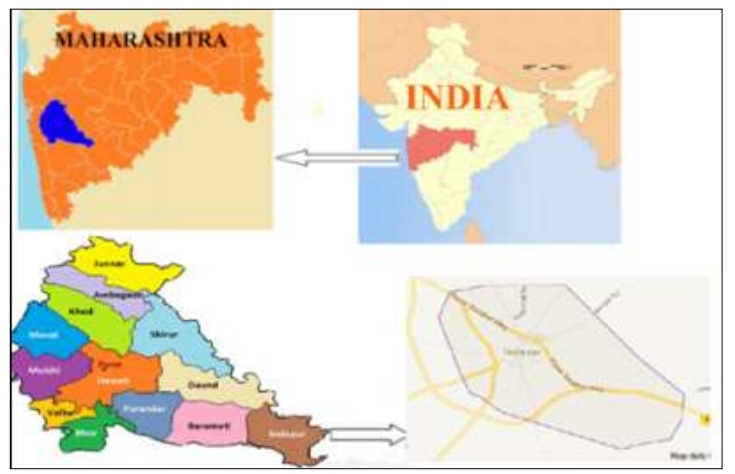

Fig.1:- Location of Indapur City, Dist.: Pune, Maharashtra state, India 


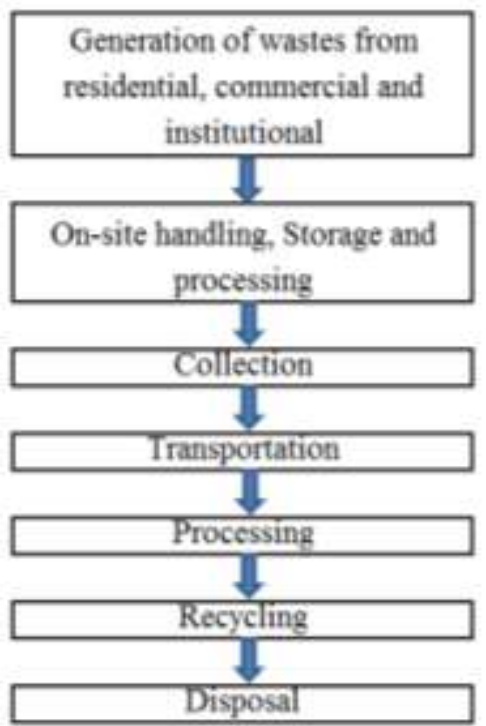

Fig. 2:- Typical flow chart of municipal SWM (Khan, Samadder, 2014)

$$
\begin{aligned}
& \text { MSW Composition of Indapur City } \begin{array}{c}
\text { Series1, } \\
\text { Compostab }
\end{array} \\
& \text { e, } 44.67
\end{aligned}
$$

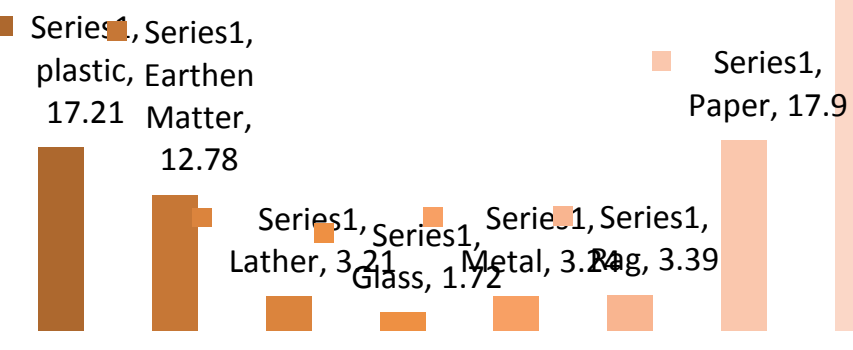

Fig. 3:- Composition of MSW of Indapur City.

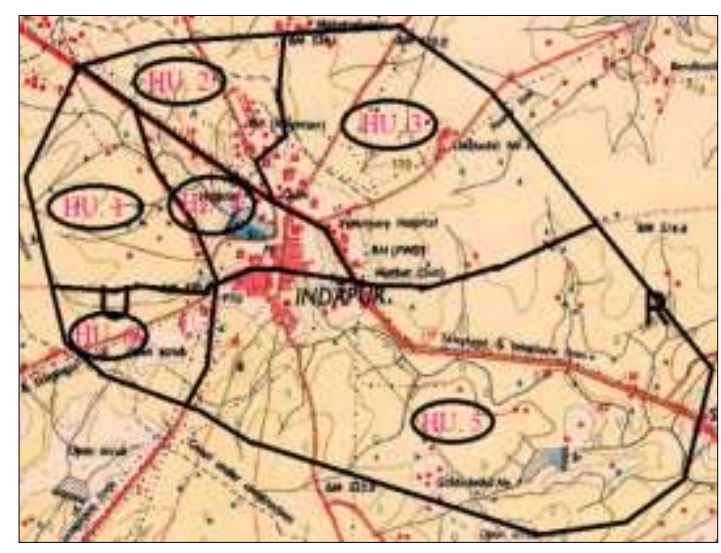

Fig. 4:- Health Units of Indapur City 


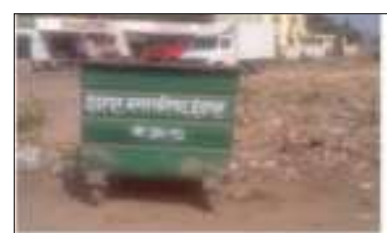

Collection Containe

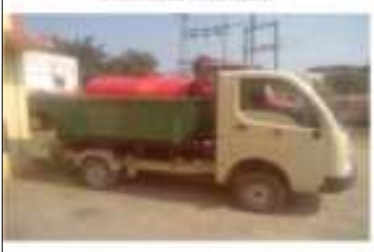

Tata ACE Hopper

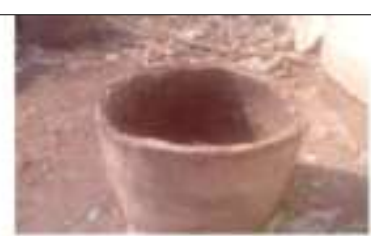

Lites Biri

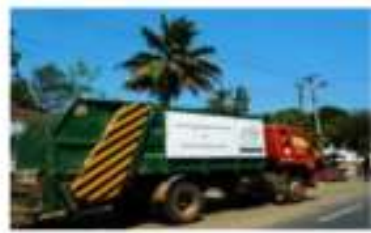

Coutaine Lift Trud

Fig. 5:- Solid waste collection equipements used in ICMC

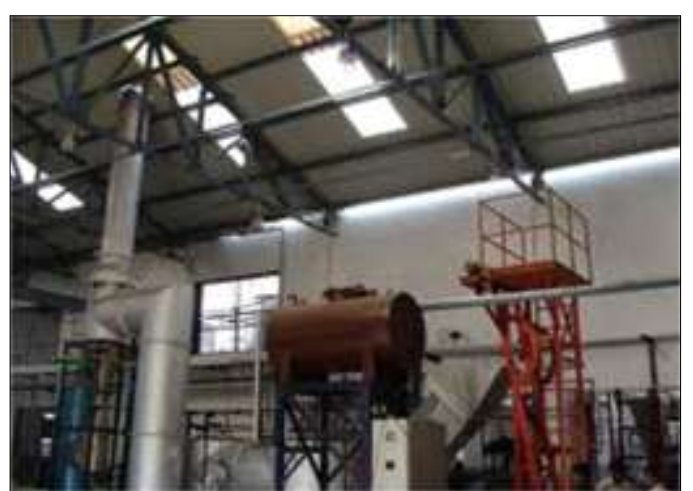

Fig. 6:- Jay Bhawani Bio-Medical Treatment Plant

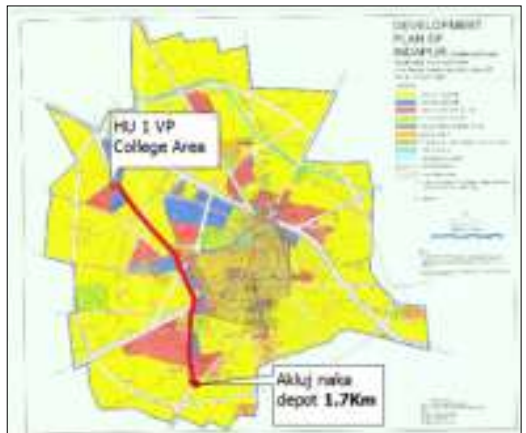

Fig. 7:- Optimized route for Health Unit - 1

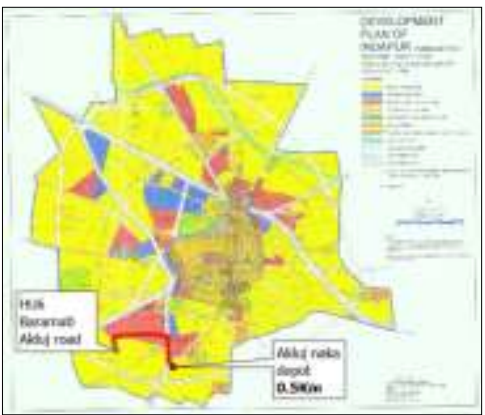

Fig. 8:- Optimized route for Health Unit - 6 


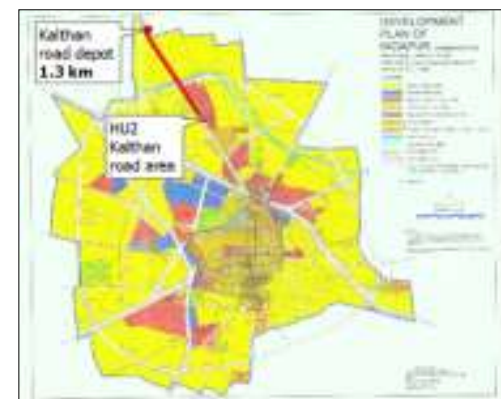

Fig. 9:- Optimized route for Health Unit - 2

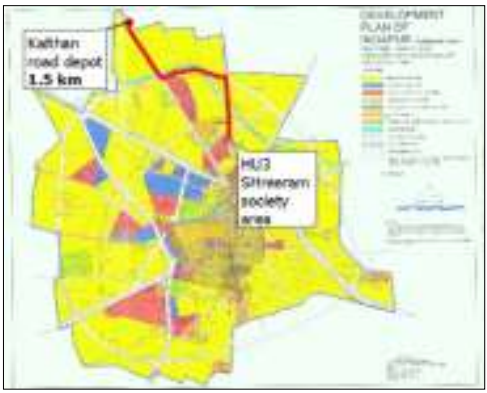

Fig. 10:- Optimized route for Health Unit - 3

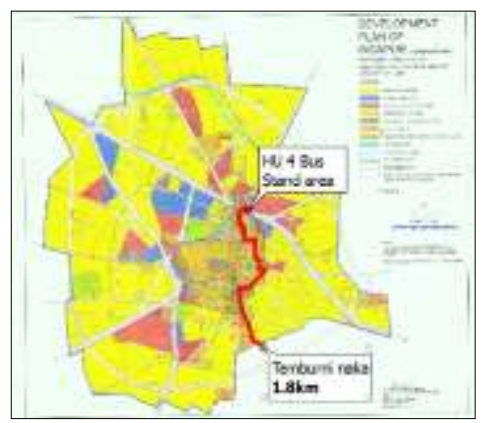

Fig. 11:- Optimized route for Health Unit - 4

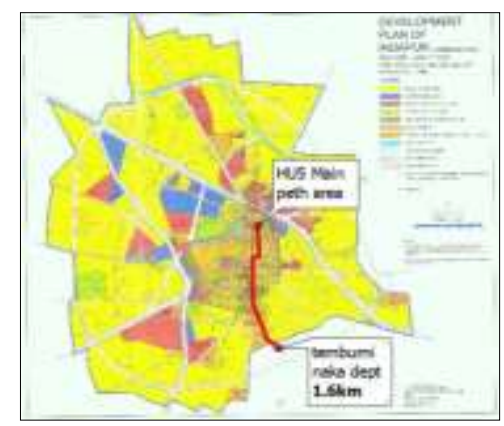

Fig. 12:- Optimized route for Health Unit - 5

Table 1:- MSW generation in India

\begin{tabular}{|l|l|l|}
\hline S. No. & Name of City & $\begin{array}{l}\text { Municipal Solid Waste } \\
\text { (Tonnes per day) } \\
\text { during 2010-11 }\end{array}$ \\
\hline 1. & Hyderabad & 4200 \\
\hline 2. & Delhi & 6800 \\
\hline 3. & Mumbai & 6500 \\
\hline
\end{tabular}




\begin{tabular}{|l|l|l|}
\hline 4. & Cheennai & 4500 \\
\hline 5. & Bangalore & 3700 \\
\hline 6. & Kolkata & 3670 \\
\hline 7. & Ahmedabad & 2300 \\
\hline 8. & Pune & 1300 \\
\hline 9. & Jammu & 300 \\
\hline 10. & Nagpur & 650 \\
\hline 11. & Nashik & 350 \\
\hline 12. & Asansol & 210 \\
\hline 13. & Gandhinagar & 97 \\
\hline 14. & Jamshedpur & 28 \\
\hline 15. & Gangtok & 26 \\
\hline 16. & Panjim & 25 \\
\hline 17. & Indapur & 10 \\
\hline
\end{tabular}

Table 2:- Population Growth: 1951-2021

\begin{tabular}{|l|l|}
\hline Year & Population \\
\hline 1951 & 4325 \\
\hline 1961 & 5728 \\
\hline 1971 & 6718 \\
\hline 1981 & 9418 \\
\hline 1991 & 17051 \\
\hline 2001 & 21592 \\
\hline 2011 & 23481 \\
\hline 2021 & $25442^{*}$ \\
\hline
\end{tabular}

*Projected Population

(Source: Census of India, 2011)

Table 3:- Zone Wise Distribution of 17 Wards

\begin{tabular}{|l|l|l|}
\hline Zone & Total No. of Wards & Ward \\
\hline 1 & 5 & $1,2,5,7$ and 16 \\
\hline 2 & 6 & $6,8,10,12,14,15$ \\
\hline 3 & 3 & 3,4 and 9 \\
\hline 4 & 3 & 11,13 and 17 \\
\hline
\end{tabular}

(Source: SWM DPR, ICMC, 2013)

Table 4:- Details of Health Units

\begin{tabular}{|l|l|l|l|}
\hline Health Unit No. & Ward No. & Main Area & SW Generated (Ton/Day) \\
\hline 1 & $1,2,5$ & Vp College Road & 1.5 \\
\hline 2 & $11,13,17$ & Kalthan Road & 1.75 \\
\hline 3 & $12,14,15$ & Shree Ram Society & 1.15 \\
\hline 4 & $3,4,9$ & Bus Stand Area & 2 \\
\hline 5 & $6,8,10$ & Main Peth & 2.6 \\
\hline 6 & 7,16 & Baramati-AklujChowk & 1.2 \\
\hline
\end{tabular}

Table 5:- Details of Collection points

\begin{tabular}{|l|l|l|}
\hline Tractor No. & wards & Collection point \\
\hline 1 & $1,2,5,7,16$ & Akluj - BaramatiChowk \\
\hline 2 & $6,8,10,12,14,15$ & Shree Ram Society \&Tembhurni Naka \\
\hline 3 & $3,4,9$ & Indapur Bus Stand \\
\hline 4 & $11,13,17$ & Kalthan Road \\
\hline
\end{tabular}


Table 6:- Distances for CASE I

\begin{tabular}{|l|l|l|}
\hline Health Units & W (ton per day) & Distance (km) \\
\cline { 3 - 3 } & & Akluj road depot \\
\hline 1 & 1.5 & 1.7 \\
\hline 2 & 1.75 & 3 \\
\hline 3 & 1.15 & 3.4 \\
\hline 4 & 2 & 3.5 \\
\hline 5 & 2.6 & 2.8 \\
\hline 6 & 1.2 & 0.5 \\
\hline
\end{tabular}

Table 7:- Distances for CASE II

\begin{tabular}{|l|l|l|l|l|}
\hline Health Unit no. & W & Distance in Km & \multicolumn{2}{l|}{} \\
\cline { 2 - 5 } & (Ton/ day) & Akluj road depot & Tembhurni Naka & Kalthan road \\
\hline 1 & 1.5 & 1.7 & - & - \\
\hline 2 & 1.75 & - & - & 1.3 \\
\hline 3 & 1.15 & - & - & 1.5 \\
\hline 4 & 2 & - & 1.8 & - \\
\hline 5 & 2.6 & - & 1.6 & - \\
\hline 6 & 1.2 & 0.5 & - & - \\
\hline
\end{tabular}

Table 8:-Number of Vehicles Required

\begin{tabular}{|l|l|l|l|l|}
\hline $\begin{array}{l}\text { Waste to be } \\
\text { transported } \\
\text { (TPD) }\end{array}$ & $\begin{array}{l}\text { Waste transported per } \\
\text { vehicle per day (TPD) }\end{array}$ & $\begin{array}{l}\text { No. } \\
\text { Vehicles } \\
\text { required }\end{array}$ & $\begin{array}{l}\text { No. } \\
\text { Drivers } \\
\text { required }\end{array}$ & $\begin{array}{l}\text { Total cost of vehicles } \\
\text { (INR in Lakh) }\end{array}$ \\
\hline 10 & 1.67 & 6 & 6 & 48 \\
\hline
\end{tabular}

Table 9:- Cost of Fuel for case I

\begin{tabular}{|l|l|l|l|l|l|l|l|}
\hline $\begin{array}{l}\text { Health } \\
\text { Unit }\end{array}$ & $\begin{array}{l}\text { W } \\
(\text { Ton })\end{array}$ & $\begin{array}{l}\text { Distance } \\
(\mathbf{K m})\end{array}$ & $\begin{array}{l}\text { Total } \\
\text { Distance } \\
\text { covered by } \\
\text { Vehicle }\end{array}$ & $\begin{array}{l}\text { Diesel } \\
\text { required } \\
\text { per day in } \\
\text { Litre }\end{array}$ & $\begin{array}{l}\text { Cost of } \\
\text { diesel per } \\
\text { day } \\
\text { (INR) }\end{array}$ & $\begin{array}{l}\text { Cost } \\
\text { Diesel of } \\
\text { Month } \\
\text { per }\end{array}$ & $\begin{array}{l}\text { Cost of diesel per } \\
\text { annum } \\
\text { (INR) }\end{array}$ \\
\hline 1 & 1.5 & 1.7 & 5.1 & 1.14 & 75 & 2250 & 27000 \\
\hline 2 & 1.75 & 3 & 9 & 2 & 130 & 8450 & 101400 \\
\hline 3 & 1.15 & 3.4 & 10.2 & 2.27 & 147.55 & 9590.75 & 115089 \\
\hline 4 & 2 & 3.5 & 10.5 & 2.34 & 152.1 & 9886.50 & 118638 \\
\hline 5 & 2.6 & 2.8 & 8.2 & 1.82 & 118.35 & 7692.75 & 92313 \\
\hline 6 & 1.2 & 0.5 & 1 & 0.25 & 16.25 & 1056.25 & 12675 \\
\hline Total & $\mathbf{1 0 . 2}$ & $\mathbf{1 4 . 9}$ & $\mathbf{4 4}$ & $\mathbf{9 . 8 2}$ & $\mathbf{1 , 2 9 7 . 5 5}$ & $\mathbf{3 8 , 9 2 6 . 2 5}$ & $\mathbf{4 , 6 7 , 1 1 5}$ \\
\hline
\end{tabular}

Table 10:-Cost of Fuel for case II

\begin{tabular}{|c|c|c|c|c|c|c|c|}
\hline $\begin{array}{l}\text { Health } \\
\text { Unit }\end{array}$ & $\begin{array}{l}\text { W } \\
\text { (Ton) }\end{array}$ & $\begin{array}{l}\text { Distance } \\
(\mathrm{Km})\end{array}$ & $\begin{array}{l}\text { Total } \\
\text { Distance } \\
\text { covered by } \\
\text { Vehicle } \\
\end{array}$ & $\begin{array}{l}\text { Diesel } \\
\text { required } \\
\text { per day } \\
\text { (litre) }\end{array}$ & $\begin{array}{lr}\text { Cost } & \text { of } \\
\text { diesel } & \text { per } \\
\text { day } & \\
\text { (INR) } & \\
\end{array}$ & $\begin{array}{lr}\text { Cost } & \text { of } \\
\text { Diesel per } \\
\text { Month } \\
(\text { INR) }\end{array}$ & $\begin{array}{l}\text { Cost of diesel per } \\
\text { annum } \\
\text { (INR) }\end{array}$ \\
\hline 1 & 1.5 & 1.7 & 5.1 & 1.14 & 75 & 2250 & 27000 \\
\hline 2 & 1.75 & 1.3 & 3.9 & 0.86 & 58 & 1740 & 28080 \\
\hline 3 & 1.15 & 1.5 & 4.5 & 01 & 66 & 1980 & 23760 \\
\hline 4 & 2 & 1.8 & 5.4 & 1.20 & 79 & 2370 & 28440 \\
\hline 5 & 2.6 & 1.6 & 4.8 & 1.07 & 70 & 2100 & 25200 \\
\hline 6 & 1.2 & 0.5 & 01 & 0.22 & 15 & 450 & 5400 \\
\hline Total & 10.2 & 8.4 & 24.7 & 5.49 & 364 & 10,890 & $1,30,680$ \\
\hline
\end{tabular}


Table 11:-Salaries

\begin{tabular}{|c|c|c|c|c|c|c|}
\hline $\begin{array}{l}\text { Total Waste to } \\
\text { be Transported } \\
\text { per day }\end{array}$ & $\begin{array}{l}\text { NO. of } \\
\text { Drivers } \\
\text { Required }\end{array}$ & $\begin{array}{l}\text { Salary per } \\
\text { month } \\
\text { (INR) }\end{array}$ & $\begin{array}{l}\text { No. of } \\
\text { Helpers } \\
\text { required }\end{array}$ & $\begin{array}{l}\text { Salary per } \\
\text { month } \\
\text { (INR) }\end{array}$ & $\begin{array}{ll}\text { Total } & \text { salary } \\
\text { per } & \text { month } \\
\text { (INR) } & \end{array}$ & $\begin{array}{l}\text { Total salary per } \\
\text { Annum (INR in } \\
\text { Lakh) }\end{array}$ \\
\hline 10.2 & 7 & 8,000 & 7 & 5,000 & 91,000 & 10.92 \\
\hline
\end{tabular}

Table 12:-O \& M of Vehicles

\begin{tabular}{|l|l|l|l|}
\hline $\begin{array}{l}\text { Total Waste to be transported } \\
\text { Tonne per day }\end{array}$ & $\begin{array}{l}\text { No. of Vehicles } \\
\text { Required }\end{array}$ & $\begin{array}{l}\text { Total cost of Vehicles } \\
\text { (INR in Lakh) }\end{array}$ & $\begin{array}{l}\text { Maintenance Cost } \\
\text { (INR in Lakh) }\end{array}$ \\
\hline 10.2 & 7 & 56 & 3.36 \\
\hline
\end{tabular}

Table 13:-Total cost of Transportation (per annum) for CASE I

\begin{tabular}{|l|l|l|l|l|}
\hline $\begin{array}{l}\text { Total Waste to be } \\
\text { transported Tonne } \\
\text { per day }\end{array}$ & $\begin{array}{l}\text { Cost of fuel } \\
\text { (INR in Lakh) }\end{array}$ & $\begin{array}{l}\text { Salaries of worker } \\
\text { (INR in Lakh) }\end{array}$ & $\begin{array}{l}\text { Cost } \\
\text { Maintenance } \\
\text { (INR in Lakh) }\end{array}$ & $\begin{array}{l}\text { Total Cost } \\
\text { (INR in Lakh) }\end{array}$ \\
\hline 10.2 & 4.67 & 10.92 & 3.36 & 18.95 \\
\hline
\end{tabular}

Table 14:-Total Cost of Transportation (per annum) for CASE II

\begin{tabular}{|l|l|l|l|l|}
\hline $\begin{array}{l}\text { Total Waste to be } \\
\text { Transported Tonne } \\
\text { per day }\end{array}$ & $\begin{array}{l}\text { Cost of fuel } \\
\text { (INR in Lakh) }\end{array}$ & $\begin{array}{l}\text { Salaries of worker } \\
\text { (INR in Lakh) }\end{array}$ & $\begin{array}{l}\text { Cost of Maintenance } \\
\text { (INR in Lakh) }\end{array}$ & $\begin{array}{l}\text { Total Cost } \\
\text { (INR in Lakh) }\end{array}$ \\
\hline 10.2 & 1.30 & 10.92 & 3.36 & 15.5 \\
\hline
\end{tabular}

\section{References:-}

1. Bundela P S, Gautam S P, Pandey A K, Awasthi MK and Sarsaiya S (2010) Municipal solid waste management in Indian cities: A review. International Journal of Environmental Sciences 1(4):591-606.

2. Das S and Bhattacharyya B K (2013) Municipal Solid Waste Characteristics and Management in Kolkata, India. International Journal of Emerging Technology and Advanced Engineering 3(2):147-152.

3. Ghosh Ruchira and Arun Kansal (2014) Urban Challenges in India and the Mission for a Sustainable Habitat. Interdisciplina 2(2): 281-304.

4. Gidde M R, Todkar V V and Kolkata K K (2008) Municipal Solid Waste Management in Emerging Mega Cities: A case study of Pune City. Indo Italian Conference on Green and Clean Environment 441-450.

5. Herat S (2009) Electronic waste: an emerging issue in solid waste management in Australia. International Journal of Environment and Waste Management 3: 120- 134.

6. Jha A K, Singh G P, Singh G P and Gupta P K (2011) Sustainable municipal solid waste management in low income group of cities: a review. Tropical Ecology 52(1): 123-131.

7. Khan D and Samadder S R (2014) Municipal solid waste management using Geographical Information System aided methods: A mini review. Waste Management \& Research 32(11) 1049-1062.

8. Rachel O A, Komine H, Yauhara K and Murakami S (2009) Municipal Solid Waste Management in Developed and Developing Countries: Japan and Nigeria as case studies. Solid Waste Audit Report. Federal Capital Territory, Abuja Nigeria 2004.

9. Rajkumar N, Subramani T and Elango L (2010) Groundwater contamination due to municipal solid waste disposal: A GIS based study in erode city. International Journal of Environmental Sciences 1: 39-55.

10. Rathi (2007) Optimization model for municipal solid waste management in Mumbai. India environment and development economics Cambridge press, United Kingdom 12:105-121.

11. Sabir Syed (2006) Solid and Liquid Waste Management. Emirates Journal for Engineering Research 11(2): 19- 36.

12. Sanjeevi V and Shahabudeen P (2015) Development of performance indicators for municipal solid waste management (PIMS): A review. Waste Management \& Research 33(12):1052-65.

13. Saxena S, Srivastava R K and Samaddar A B (2010) Towards sustainable municipal solid waste management in Allahabad City. Journal of Management of Environmental Quality 21(3):308-323.

14. Jagdeep Singh, Rafael Laurenti, RajibSinha and Bjorn Frostell (2014) Progress and challenges to the global waste management system. Waste Management \& Research 32(9) 800-812.

15. Ogu V I (2000) Private sector participation and municipal waste management in Benin City. Nigeria Environment \& Urbanization 12(2):103-117.

16. Zhu D, Asnani PH, Zurbrugg C, Anapolsky S and Mani S (2008) Improving Municipal Solid Waste Management in India. A Source Book for Policy Makers and Practitioners. World Bank, Washington D.C. 